
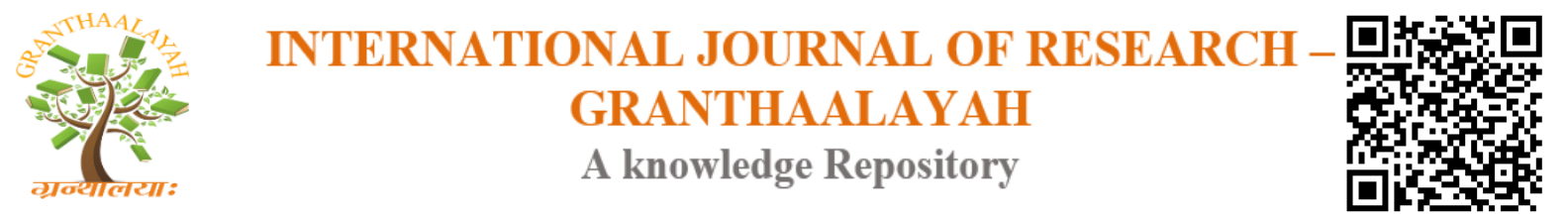

Management

\title{
STUDENTS PERCEPTION ON ACTIVE LEARNING: PRACTICAL IMPLICATIONS
}

\author{
Tamrat Dina Teressa *1 \\ ${ }^{* 1}$ Department of Management, College of Business and Economics, Gambella University, PO \\ Box 126, Gambella, Ethiopia
}

\begin{abstract}
The intention of educational authorities in different level is to implement active learning in Educational institutions including higher education institutions. Consequently, the need for this research was to examine the Practice and challenges of active learning: practical implications in Gambella University. The objective of researcher to undertake this research was to identify whether his on the right track in his teaching and to examine the practice and challenges of active learning practical implication. In order to achieve the objectives of the action research, the researcher has collected primary data directly from the class students to obtain tangible data from respondents. The researcher used questionnaire to collect quantitative data from 30 students which incorporates $50 \%$ of the class. The researcher was used both close-ended and open-ended questionnaire for this study. Since there is no previous research study conducted concerning the practices and challenges of active learning in the under consideration, the proportion of a target population was taken from 3rd year management department students. The finding depicts that most of students are not interested in active learning method, Students are in high satisfaction in their existing entrepreneurship learning, The respondents are very interesting in individual learning rather than group or cooperative learning, Most of students are interested in lecture method learning maximum number of students were agree that the existing lecture speed of presentation was fast, More than half of the respondents were agree that the existing way of teaching entrepreneurship was understandable. And Maximum number of students were agreed that the existing evaluation technique can measure students' performance.
\end{abstract}

Keywords: Active Learning; Action Research; Achievement; Entrepreneurship.

Cite This Article: Tamrat Dina Teressa. (2018). "STUDENTS PERCEPTION ON ACTIVE LEARNING: PRACTICAL IMPLICATIONS." International Journal of Research - Granthaalayah, 6(7), 200-209. https://doi.org/10.29121/granthaalayah.v6.i7.2018.1299.

\section{Introduction}

The purpose of this action research is to determine how students have positive perception in active learning and how it affects students' achievement in an entrepreneurship class. Action research an appropriate paradigm for improving everyday classroom practice. Business educators work in their 
own environments, with their own students, implementing their own pedagogies with the challenge and responsibility to improve their own teaching and learning practices. Basically, improving teachers current practice and at the same time improving their understanding and contribution to theory can help dissolve the differentiation between teaching and students achievement. Stephen Corey (1953, p70) profoundly states: "We are convinced that the disposition to stud the consequences of our own teaching is more likely to change and improve our practices than is reading about what someone else has discovered of his teaching."

On the other hand, Action research allows business educators to learn about themselves, their students, and their colleagues in a meaningful way intent of improving their teaching. Systematically incorporating critical reflection along with professional conversations with colleagues in the form of an action research project can be a significant type of professional development (Ferrance, 2000).

Action research treats our own observations and thinking as data which must be made available for analysis and interpretation not only for our first-person inquiry but also for our colleagues involved in the second-person inquiry. Therefore, detailed and prompt recording of our personal observations and thoughts of classroom events and experiences is critical for facilitating our own personal learning, as well as, to form the collaborative basis for self-reflection.

Faculty/researchers should explicitly consider the learning theory their pedagogies are intended to implement and evaluate their learning outcomes in light of that particular theoretical framework. Revised intervention strategies should then be based on multiple viewpoints, interpretations, and evidence as well as theory. Thus, action research is an appropriate paradigm for enhancing our current teaching in addition to having the potential to contribute to the scholarship of teaching and learning.

The primary reason that I conduct this action research is to identify my weaknesses and improve my teaching methods and develop my teaching profession. Professional development is the ability as an educator to focus growth specifically on things that I identify as being an area of my professional practice that I would like to see improve. As I've mentioned, the focus is on $m y$ classroom, my students, and their improved achievement. Furthermore, once I had results from my action research inquiry, I have the ability to take action immediately. When I systematically investigate my own teaching methods, etc., I collect data on my students and on my teaching; I could know immediately what should be improved and what might not be improved in my teaching practice.

\section{Materials and Methods}

\subsection{Description of the Study Area}

Based on the 2007 Census conducted by the Central Statistical Agency of Ethiopia (CSA), the Gambela Region has total population of 307,096, consisting of 159,787 men and 147,309 women; urban inhabitants number 77,925 or $25.37 \%$ of the population. With an estimated area of $29,782.82$ square kilometers, this region has an estimated density of 10 people per square kilometer. For the entire Region 66,467 households were counted, which results in an average for the Region of 4.6 persons to a household, with urban households having on average 3.8 and rural households 4.9 
people. The Gambela Region is mainly inhabited by various Nilotic ethnic minority populations (Nuer 46.66\%, Anuak 21.16\%, Mezhenger 4\%), as well as some Omotic groups (Kafficho 5.04\%, Shakacho 2.27\%), Afro-Asiatic populations (Amhara 8.42\%, Oromo 4.83\%, Kambaata 1.44\%, Tigray $1.32 \%$ ), and other ethnic groups predominantly from southern Ethiopia $4.86 \%$. Nuer is spoken as a first language by $48.35 \%, 22.02 \%$ speak Anuak, $11.11 \%$ Amharic, $4.85 \%$ Afaan Oromoo, $4.65 \%$ Kafa, 2.48\% Shakacho, $1.47 \%$ speak Kambaata, and $1.32 \%$ speak Tigrinya; the remaining $3.75 \%$ spoke all other primary languages reported. $70.1 \%$ of the region's population are Protestant, 16.8\% Orthodox Christian, 4.9\% Muslim, 3.8\% practice traditional religions, 3.4\% Catholic[3] The projected population for 2017 was 435,999.[2]

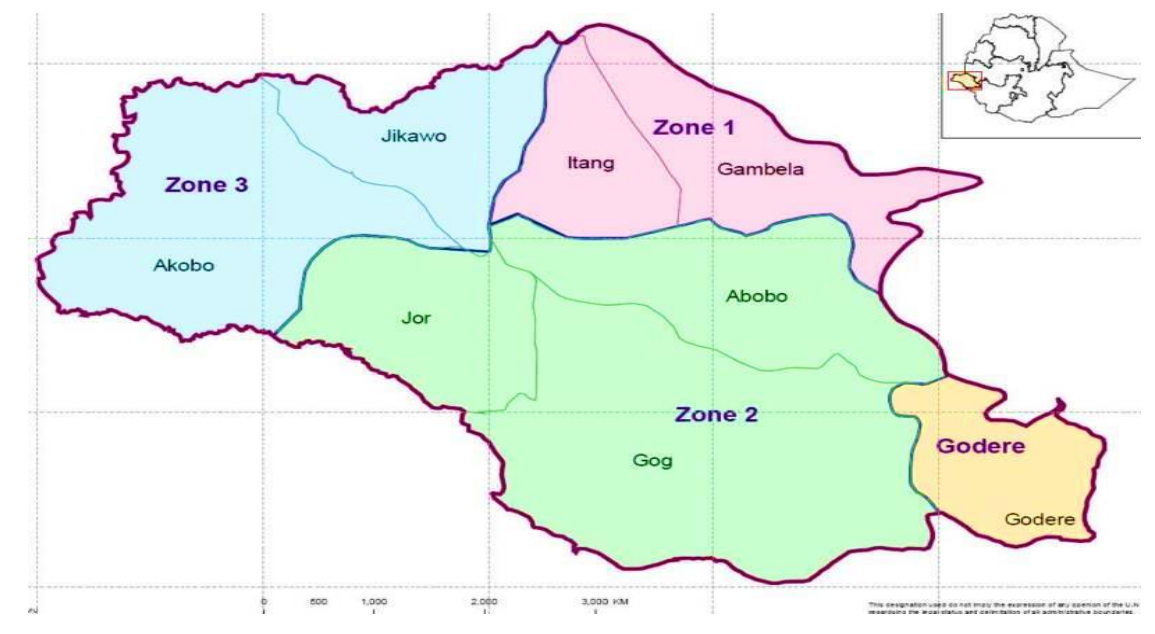

\section{Gambella University}

Gambella University is one of the recently established higher learning institutions in Ethiopia. Its milestone had been laid by Prime Minister Haylemareiam Desaleng on 28th, April, 2014. It is located at Gambella town, the capital of GPNRS, nick name 'Agarfa' and it is situated about 766 $\mathrm{km}$ south west of Addis Ababa Ethiopia. It was primarily established as Gambella Agriculture Technical Vocational educational Training (GATVET) College which was organized and managed by Federal Agriculture Minister and GPNRS from 2002 to 2012. During the ten years (2002-2012) staying, 658 graduated -animal science, 646 - natural resource, 646 - plant science; total 1950 students had been graduated in diploma program. Moreover, 493 General Agriculture students had been graduated with certificate program. Then; in the meantime, the college was connected to Metu University as one of its branch from 2012-2013/14.

The establishment of Gambella University in 2014 was a new chapter in the history of the Gambella Region. In the subsequent months, the independent Gambella University regulation had been ratified by the Federal Minister Council, Article Number 317/06; soon after, Five Hundred Fourteen students were assigned so as to study into one Faculty, one college and thirteen departments.

Even though Gambella University is at its infancy stage, it is growing fast. Currently the University runs thirteen undergraduate programs which are divided in to Agriculture and Natural Resource College and Business and Economics faculty. For a time being it has one campus at Gambella town. The University has the vision of "envisaging one of the recognized academic and research centers in Africa by 2030". 


\section{Methodology and Design}

\subsection{Introduction}

The main objective of this action research is to assess the practices and challenges of active learning in $3^{\text {rd }}$ year management department: In this study, the researcher was employed descriptive methods that engaged the quantitative and qualitative data gathering and interpretation. This chapter includes types of research, sources of data, data collection methods, sampling design, sampling techniques, data analysis methods and confidentiality.

\subsection{Types of Research}

The researcher was used both qualitative and quantitative methods of research. Because, the research was focused on both qualitative and quantitative research approach that suits for the purpose of analysis and for interpretation of data in order to answer the research questions and to attain the research objectives through expressing to the qualitative data as well as measured and explained.

\subsection{Sources of Data}

The source of data was primary sources. In order to achieve the objectives of the action research, the researcher has collected primary data directly from the class students to obtain tangible data from respondents.

\subsection{Data Collection Methods}

\section{Methodology}

For data collection and analysis both qualitative and quantitative methods were employed and various techniques such as questionnaire survey, semi-structured interview, Focus Group Discussion (FGD), researcher used two types of questionnaires designed and filled by students, Focus group discussions were also held with 10 students (5 top achievers and 5 lower achievers).

\section{Questionnaire}

The researcher used questionnaire to collect quantitative data from 30 students which incorporates $50 \%$ of the class. The researcher was used both close-ended and open-ended questionnaire for this study.

\subsection{Sampling Design}

\subsubsection{Population and Sample Size}

Since there is no previous research study conducted concerning the practices and challenges of active learning in the under consideration, the proportion of a target study area was taken from 3rd year management department students which consists of 59 students class size. 


\subsection{Sampling Technique}

The research was descriptive type. Thus, non-probability sampling such as purposive sampling was used to select the respondents. Then, it was applied for the students learning in the class.

\subsection{Methods of Data Analysis}

The information that was gathered, from primary data was analyzed and presented in different forms. The researcher analyzes, describe, discuss, code and qualify the primary data using tables, frequency and percentages to make interpretation logical.

\section{Data Analysis and Presentation}

\subsection{Introduction}

The previous chapter deals with research methodology and design. This chapter dedicated to data presentation, analysis and interpretation.

The topic provides data analysis and assessment collected from questionnaire. The purpose of data analysis is to assess the practices and challenges of active learning in $3^{\text {rd }}$ year management department; under this analysis the perception of the students in the class under consideration was analyised.

\subsection{Presentation and Analysis of Student's Response}

30 questionnaires were prepared and distributed to the students but 27 were properly filled out and returned.

Table1: Questionnaires Response Rate

\begin{tabular}{|l|l|}
\hline Population size & 58 \\
\hline Sample size & 30 \\
\hline Completed and returned questionnaire & 27 \\
\hline Response rate & $90 \%$ \\
\hline
\end{tabular}

Source: source out come and own computation

The questionnaire was physically distributed to 30 management department students. Out of 30 questionnaires 27 were completed and collected. As a result the response rate $90 \%$.

Table 2: Demographic Characteristics of Respondents of the respondent

Source, questionnaire

\begin{tabular}{|l|l|l|}
\hline Sex & Number of respondents & Percentage \\
\hline Male & 24 & $88.89 \%$ \\
\hline Female & 3 & $11.11 \%$ \\
\hline Total & 27 & $100 \%$ \\
\hline
\end{tabular}

As shown in table 2 above from, respondent of 24, 3 were mails and female respectively which depicts that the number of males take the majority of respondents. 
Table 3: Students response on their own preferences, whether their interests lie primarily in active learning

\begin{tabular}{|l|l|l|l|}
\hline Alternative & Frequency & Percentage & Total \\
\hline Male & 24 & 88.9 & 88.9 \\
\hline Female & 3 & 11.1 & 11.1 \\
\hline & & & 100 \\
\hline
\end{tabular}

Table 3: indicates that $88.9 \%$ of respondents were responded they are interested in active learning method while $11.1 \%$ of the respondents disagree in active learning. This indicates that almost all female students are not interested in active learning method.

Table 4: Student's evaluation their overall satisfaction with their current entrepreneurship leaning method

\begin{tabular}{|l|l|l|l|}
\hline Alternative & Frequency & Percentage & Total \\
\hline Very high & 4 & 14.8 & 14.8 \\
\hline high & 18 & 66.7 & 81.5 \\
\hline Average & 4 & 14.8 & 96.3 \\
\hline Vary low & 1 & 3.7 & 3.7 \\
\hline total & 27 & 100 & 100 \\
\hline
\end{tabular}

Table 4: shows that most of respondents $(96.3 \%)$ are in high satisfaction and nearest to those respondents (81.5) are satisfied in their entrepreneurship learning. Similarly, most of the respondants of open ended questionairs respond that my currents teaching method is average, hence, I understood that there are some actions to be taken to satisfy my students.

Table 5: How stressful was their entrepreneurship learning environment?

\begin{tabular}{|l|l|l|l|}
\hline Alternative & Frequency & Percentage & Total \\
\hline Very high & 4 & 14.9 & 14.9 \\
\hline high & 13 & 48.1 & 17 \\
\hline low & 10 & 37 & 63 \\
\hline total & 27 & 100 & 100 \\
\hline
\end{tabular}

From Table 5: one can understand that $63 \%$ the respondents have low stressful in their entrepreneurship learning environment. Correspondingly the openended respondants agree that they have no any stress in their learning environment. So that the learning environment is conducive for their learning.

Table 6: evaluating individual learning

\begin{tabular}{|l|l|l|l|}
\hline Alternative & Frequency & Percentage & Total \\
\hline Very interesting & 21 & 77.8 & 77.8 \\
\hline Not interesting & 6 & 22.2 & 22.2 \\
\hline total & 27 & 100 & 100 \\
\hline
\end{tabular}

Table 6: Demonstrates that $77.8 \%$ of the respondents were very interesting in individual learning rather than group or cooperative learning. On the other hand, $22.2 \%$ of the respondants were not 
interesting in individual learning. From this one can understand that the teacher has to do more to enhance awareness of the students.

Table 7: students' perception in importance of doing any activity in group or in 1 to 5 cooperative learning

\begin{tabular}{|l|l|l|l|}
\hline Alternative & Frequency & Percentage & Total \\
\hline Yes & 4 & 14.8 & 14.8 \\
\hline No & 23 & 85.2 & 85.2 \\
\hline Total & 27 & 100 & 100 \\
\hline
\end{tabular}

Table 7: above reveal that most of the respondents $(85.2 \%)$ were not willing in group or cooperative learning. By the same token respondents point out that doing activities with other class members might consume their time if they use to do their activities in group.

Table 8: respondent's evaluation of individual learning

\begin{tabular}{|l|l|l|l|}
\hline Alternative & Frequency & Percentage & Total \\
\hline Very interesting & 21 & 77.8 & 77.8 \\
\hline Not interesting & 6 & 22.2 & 22.2 \\
\hline Total & 27 & 100 & 100 \\
\hline
\end{tabular}

Table 8 shows that most of the respondents $(77.8 \%)$ are very interested in individual learning which is opposite to group or cooperative learning. The reason behind is that some students are not contributing in the activities as a result only few students are carrying out the given activities.

Table 9: The extent of respondent's agreement in Lecture method learning

\begin{tabular}{|l|l|l|l|}
\hline Extent of agreement & Frequency & Percentage & Total \\
\hline Very agree & 6 & 22.2 & 22.2 \\
\hline agree & 21 & 77.8 & 77.8 \\
\hline Total & 27 & 100 & 100 \\
\hline
\end{tabular}

Table 9 describes that almost three forth of the respondents $(77.8 \%)$ are agree in lecture learning method while $22.2 \%$ of the respondents shows that they are very agree in lecture method learning. This idea indicates that most of the students interest is just being passive learner in the class.

Table 10: the extent of the respondent's agreement in my teaching

\begin{tabular}{|l|l|l|l|}
\hline Degree of agreement & Frequency & Percentage & Total \\
\hline Very agree & 6 & 22.2 & 22.2 \\
\hline agree & 20 & 74.1 & 74.1 \\
\hline disagree & 1 & 3.7 & 3.7 \\
\hline Total & $\mathbf{2 7}$ & $\mathbf{1 0 0}$ & $\mathbf{1 0 0}$ \\
\hline
\end{tabular}

Table 10: Shows $74.1 \%$ of the respondents agree in the current methods of teaching. On the contrary, only $3.7 \%$ of the respondents were disagreeing in the current method of teaching. To sum up most students are interesting in the current teaching style. 
Table 11: the extent of agreement in my lecture speed

\begin{tabular}{|l|l|l|l|}
\hline Degree of agreement & Frequency & Percentage & Total \\
\hline Very agree & 4 & 14.8 & 14.8 \\
\hline agree & 11 & 40.7 & 40.7 \\
\hline Disagree & 10 & 37 & 37 \\
\hline Strongly agree & 2 & $\mathbf{7 . 4}$ & $\mathbf{7 . 4}$ \\
\hline Total & $\mathbf{2 7}$ & $\mathbf{1 0 0}$ & $\mathbf{1 0 0}$ \\
\hline
\end{tabular}

Table 11: indicates that among the respondents $40.7 \%$ of the respondents were agree that the current teaching speed of presentation was fast. This shows that there is a need to slow-dawn the speed of current lecture.

Table 12: the extent of understandability of my methods of teaching evaluated by respondents

\begin{tabular}{|l|l|l|l|}
\hline Degree of agreement & Frequency & Percentage & Total \\
\hline Very agree & 11 & 40.7 & 40.7 \\
\hline agree & 15 & 55.6 & 55.6 \\
\hline Disagree & 1 & 3.7 & 3.7 \\
\hline Total & $\mathbf{2 7}$ & $\mathbf{1 0 0}$ & $\mathbf{1 0 0}$ \\
\hline
\end{tabular}

Table 12, describes that $55.6 \%$ of the respondents are agree that the way I am teaching entrepreneurship was understandable. On the Contrary $3.7 \%$ of the respondents are disagree the understandability of my teaching.

Table 13: Respondents rating whether on my methods of evaluation measure students' performance

\begin{tabular}{|l|l|l|l|}
\hline Degree of agreement & Frequency & Percentage & Total \\
\hline Very agree & 8 & 29.6 & 29.6 \\
\hline agree & 14 & 51.9 & 51.9 \\
\hline Disagree & 4 & 14.8 & 14.8 \\
\hline Strongly disagree & $\mathbf{1}$ & $\mathbf{3 7}$ & $\mathbf{3 7}$ \\
\hline Total & $\mathbf{2 7}$ & $\mathbf{1 0 0}$ & $\mathbf{1 0 0}$ \\
\hline
\end{tabular}

Table 13 indicates that $51.9 \%$ of the respondents were agree that the existing evaluation method can measure students' performance but insignificant $(3.7 \%)$ of the respondents were strongly disagree that the evaluation methods does not measure students' performance. Therefore, the existing evaluation method was interesting and acceptable by most of the students. So that the lecturer has to keep performing as per the previous way of evaluatin his students.

\section{Conclusion}

\subsection{Concussion}

The intention of the researcher is to implement active learning in the classroom. Consequently, the need for this research was to examine the Practice and challenges of active learning: practical implications in Gambella University. The objective of researcher to undertake this research was to identify whether his on the right track in his teaching in line with the method he use in class room 
and to examine the practice and challenges of active learning practical implication. In order to achieve the objectives of the research, the researcher has collected primary data directly from the class students to obtain tangible data from respondents. Hence, per the response obtained from respondents the result shows the following realities.

- Even though the almost all the educational authorities and specialists in the field belive in active learning most of students are not interested in active learning method. Rather they are interested lecture method and to perform individually.

- Students are highly satisfied in their existing entrepreneurship teaching learning practice. Because their instructor use to teach mixed method (both lecture and active teaching learning method).

- The respondents were very interested in individual learning rather than group or cooperative learning. Their reason was that some students could not play any role in active learning and are dependent on others and this results more work load on those students who are actively participating in group work.

- Most of students are interested in lecture method learning maximum number of students were agree that the existing lecture speed of presentation was fast. Hence, the teacher need to improve his lecture speed.

- More than half of the respondents were agree that the existing way of teaching entrepreneurship was understandable.

- Most number of students were approved that the existing evaluation technique can measure students' performance in terms of the three learning domains(cognitive, affective and psychomotor domains).

\section{References}

[1] de Baessa, Yetilú, Ray Chesterfield, and Tanya Ramos. 2002. "Active Learning and Democratic Behavior in Guatemalan Rural Primary Schools." Compare: A Journal of Comparative and International Education 32 (2): 205-218

[2] Dewey, John. 1900. The School and Society \& the Child and the Curriculum. Chicago: University of Chicago Press.

[3] Dewey, John. 1916. Democracy and Education. New York: Macmillan.Freire, Paulo. 1970/1990. Pedagogy of the Oppressed. New York:

[4] Ed 82:455-472,

[5] Ferrance, E. (2000) 'Action research'. In Themes in Education (series). Providence, RI: Brown University / Northeast and Islands Regional Educational Laboratory.

[6] Mason, L. and Boscolo,P. (2000). Writing and conceptual change. What changes? Instructional

[7] McNiff, J. (2002) Action research for professional development: Concise advice for new action researchers (3rd ed.). Dorset, England: Author. Retrieved on March 7, 2013, from www.jeanmcniff.com/userfiles/file/Publications/AR\%20Booklet.doc..

[8] Mills, G. E. (2011) Action research: A guide for the teacher researcher (4th ed.). Boston: Pearson.Oliver, B. (1980) 'Action research for in-service training'. Educational Leadership, 37(5), 394-395.

[9] Niemi, Hannele. 1997. "Active Learning by Teachers. In Active Learning for Students and Teachers: Reports from Eight Countries, ed. David Stern and Günter L. Huber. New York: Peter Lang.

[10] Niemi, Hannele. 2002. "Active Learning - A Cultural Change Needed in Teacher Education and Schools." Teaching and Teacher Education 18 (7): 763-780. 
[11] Prince, Michael. 2004. "Does Active Learning Work? A Review of the Research." Journal of Engineering Education 93 (3):223-231.

[12] Rousseau, Jean-Jacques. 1762/1979. Emile. New York: Basic Books. Rusk, Robert, and James Scotland. 1979. Doctrines of the Great Educators. New York: St. Martin's Press.

[13] Smith, M. K. (2001) Kurt Lewin: Groups, experiential learning, and action research. [Web site]. Retrieved on March 11, 2013, from www.infed.org/thinkers/et-lewin.htm.

[14] Stern, David, and Günter Huber, eds.1997. Active Learning for Students and Teachers: Reports from Eight Countries. New York: Peter Lang.

[15] Weaver, G.C. (1996) Strategies in K-12 Science Instruction to Promote Conceptual Change. Sci

[16] Welch, A.R. (1997). The peripatetic professor: The internationalization of the academic profession. Higher Education, 34(3), 323-345.

*Corresponding author.

E-mail address: dintamrat@ gmail.com 